International Research Journal of Management, IT \& Social Sciences
Available online at https://sloap.org/journals/index.php/irjmis/
Vol. 7 No. 6, November 2020, pages: 124-130
ISSN: 2395-7492
https://doi.org/10.21744/irjmis.v7n6.1022

\title{
The Use of E-Commerce During COVID-19 Pandemic Towards Revenue and Volume of MSMEs Sales
}

\author{
I.A. Cynthia Saisaria Mandasari ${ }^{\text {a }}$ \\ I Gede Surya Pratama ${ }^{b}$
}

\section{Article history:}

Submitted: 18 August 2020

Revised: 09 September 2020

Accepted: 27 October 2020

\section{Keywords:}

COVID-19;

e-commerce;

MSMEs;

revenue;

sales volume;

\begin{abstract}
A large number of MSMEs in Denpasar City must be able to overcome the challenges caused by the COVID-19 virus and must be able to reach changes around it. Marketing communication must be done as well and as effectively as possible to potential customers. The use of online strategies with ecommerce media is currently the best solution for MSMEs. This is because promotion through online media is easier to reach consumers in terms of introducing or selling their products without having to meet face to face. Ecommerce makes it easier for consumers and producers to make transactions. The purpose of this research is to examine the effect of e-commerce on the income and sales volume of MSMEs in Denpasar City. Targeting MSMEs as research respondents. The data collection technique used is a questionnaire technique with a sample of 100 MSME owners. The data obtained will be analyzed using a partial least square (PLS) based structural technique. The results of this study are expected to be able to contribute ideas to related parties, in this case, the community, government, and MSMEs players related to the effect of e-commerce on the income and sales volume of MSMEs.
\end{abstract}

International research journal of management, IT and social sciences (C) 2020. This is an open access article under the CC BY-NC-ND license (https://creativecommons.org/licenses/by-nc-nd/4.0/).

\section{Corresponding author:}

I.A. Cynthia Saisaria Mandasari,

Faculty of Economics and Business, Warmadewa University, Denpasar, Indonesia.

Email address: cynthiafeunwar@gmail.com

a Faculty of Economics and Business, Warmadewa University, Denpasar, Indonesia

Faculty of Economics and Business, Warmadewa University, Denpasar, Indonesia 


\section{Introduction}

The International Monetary Fund (IMF) stated that the global economy and finance are currently experiencing a crisis due to the coronavirus pandemic (COVID-19). Because this virus has plagued almost all countries and at the same time paralyzes the economy (Klok et al., 2020).

Responding to this coronavirus pandemic in the resulting economic and social context, quoted from liputan6.com, Indonesian President Jokowi Widodo continues to seek to ask businesses to take advantage of digital platforms to maximize their respective businesses. "Even though there is a policy of reducing interaction, I ask business actors, MSME players, to maximize the use of online services," said Jokowi in Jakarta.

MSME is one of the pillars of the economy in Indonesia. Data from umkm-id.com, according to the Coordinating Ministry for Economic Affairs, in 2018 the role of MSMEs in GDP grew by 60.34 percent. In terms of numbers, small businesses in Indonesia contributed more to GDP, reaching 93.4 percent, then medium-sized businesses 5.1 percent, and large businesses only 1 percent. However, in principle, this figure does not show any changes every year. Therefore, for Indonesia's economic foundation to be maintained and strengthened, Indonesia needs to increase this figure, so that it does not only survive in small businesses. However, the middle and upper sectors also need to be encouraged. It is time for MSME to go to class (Chawan \& Vasudevan, 2014; Raut et al., 2017).

On the island of Bali, the number of MSMEs is quite a lot, until now the number of MSMEs in Bali is recorded at 265,558 units. Most MSMEs are found in Gianyar Regency (91,511), then in Karangasem (38,954), Bangli (35,263), Badung (26,863), Jembrana (20,512), Tabanan (20,032), Denpasar (11,515), Buleleng (11,196), and Klungkung $(9,712)$. MSMEs that dominate are the handicraft, culinary, and fashion industries. When viewed from the area that stands out due to the existence of this UMKM, one of them is Denpasar. In general, MSMEs often face conventional problems that are not completely resolved, such as problems with human resource capacity, ownership, financing, marketing, and various other problems related to business management, so that MSMEs find it difficult to compete with large companies (Abor \& Quartey, 2010). However, MSMEs are a creative industry that has been able to provide a sizable income for the island of Bali.

The use of online strategies with e-commerce media is currently the best solution for MSMEs. This is because promotion through online media is easier to reach consumers in terms of introducing or selling their products without having to meet face to face (Corbitt et al., 2003; Gunasekaran et al., 2002). E-commerce makes it easier for consumers and producers to make transactions. The public needs to know who acts through the advertising media (Mursid, 2017). In Indonesia, various kinds of e-commerce can be used by MSME players to serve their consumers online, such as GO-JEK, Grab, Tokopedia, Lazada, Bukalapak, Shopee, Blibli.com, Olx, and others. According to Helmania \& Afrinawat (2018), the use of e-commerce can affect the increase in business income for MSMEs. Another study conducted by Suprapto (2016), states that e-commerce also affects the level of sales at MSMEs. Based on the above background, the conceptual framework in this study is as follows:

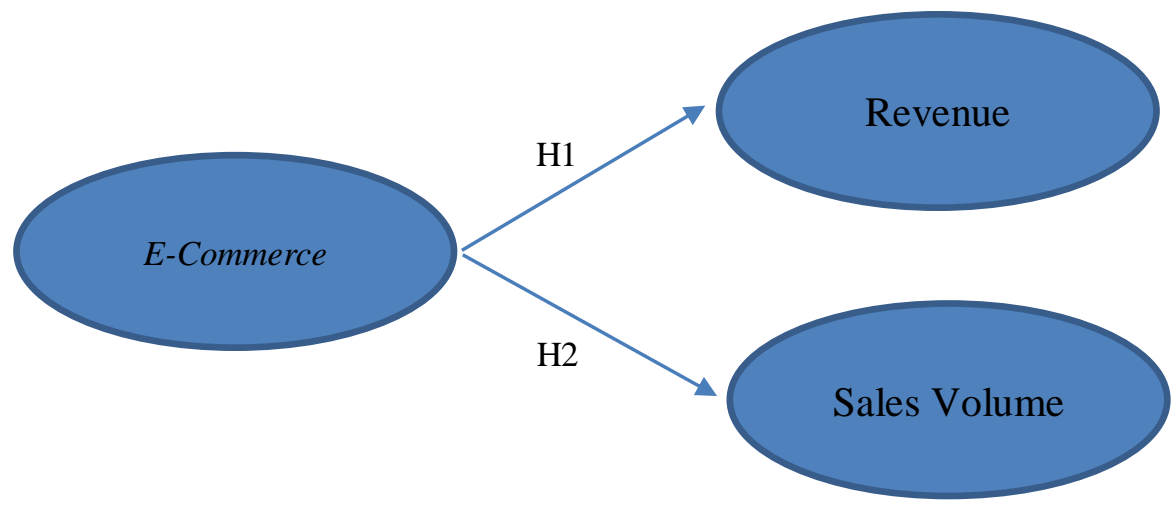

Figure 1. Framework

From the conceptual framework above, the research hypothesis is as follows:

H1: E-Commerce has a positive and significant effect on income.

$\mathrm{H} 2$ : E-Commerce has a positive and significant effect on sales volume

Mandasari, I. C. S. ., \& Pratama, I. G. S. . (2020). The use of e-commerce during COVID-19 pandemic towards revenue and volume of MSMEs sales. International Research Journal of Management, IT and Social Sciences, 7(6), 124-130. https://doi.org/10.21744/irjmis.v7n6.1022 


\section{Materials and Methods}

The location of this research was conducted in Denpasar City with the object of research, namely the impact of using e-commerce during the COVID-19 pandemic on the income and sales volume of MSMEs in Denpasar City (Shih et al., 2012; Stokes, 2005). Population in this study, namely the owners of MSMEs in Denpasar City with a sample measured using the Slovin technique of 100 respondents. According to Sugiyono (2012), purposive sampling is a technique of determining the sample with certain considerations. The sample considerations used in this study are MSME owners who are domiciled in Denpasar City and MSME owners who use e-commerce for at least 1 month.

The data in this study were collected through a research instrument in the form of a questionnaire. Researchers distributed questionnaires directly to the owners of MSMEs in Denpasar City and distributed questionnaires (Dewi, 2019). The data collection method is a systematic and standard procedure for obtaining the required data (Siregar, 2010).

This study uses a structural equation model based on partial least square (PLS). SmartPLS 3 software is used to help analyze the relationship between variables. According to Abdillah \& Jogiyanto (2009), PLS is a variant-based structural equation analysis (SEM) that can simultaneously test the measurement model as well as testing the structural model used for causality testing (hypothesis testing with predictive models).

\section{Results and Discussions}

\subsection{Evaluation of measurement model (Outer Model)}

\section{Convergent validity}

Convergent validity testing shows each construct has an AVE value of more than 0.50 , which can be seen in Table 1 . Each indicator was also found to have an outer loading value greater than 0.50 , which can be seen in Table 2. Explained that the measurement met the criteria for convergent validity.

Table 1

AVE

\begin{tabular}{lc}
\hline Variable & AVE \\
\hline E-Commerce (X) & 0,574 \\
Revenue (Y1) & 0,803 \\
Sales VolumeY2) & 0,778 \\
\hline
\end{tabular}

Primary Data, 2020

Table 2

Outer loadings

\begin{tabular}{|c|c|c|c|}
\hline & E-Commerce (X) & Revenue (Y1) & Sales Volume (Y2) \\
\hline Price (X.1) & 0,803 & & \\
\hline Comfort (X.2) & 0,851 & & \\
\hline Completeness of products sold (X.3) & 0,749 & & \\
\hline Convenience (X.4) & 0,706 & & \\
\hline Information provided by E-commerce (X.5) & 0,665 & & \\
\hline Total cost (Y1.1) & & 0,881 & \\
\hline Total Revenue (Y1.2) & & 0,933 & \\
\hline Time (Y1.3) & & 0,873 & \\
\hline Reaching Sales Volume (Y2.1) & & & 0,886 \\
\hline Earning Profit (Y2.2) & & & 0,899 \\
\hline Supporting community growth (Y2.3) & & & 0,861 \\
\hline
\end{tabular}

Primary Data, 2020 
Discriminant validity

In discriminant validity testing, the output results show the cross-loading value of the indicator for each construct is greater than the cross-loading value between constructs and other constructs.

Table 3

Cross Loadings

\begin{tabular}{lccc}
\hline & E-Commerce (X) & Revenue (Y1) & Sales Volume (Y2) \\
\hline Price (X.1) & $\mathbf{0 , 8 0 3}$ & 0,493 & 0,530 \\
Comfort (X.2) & $\mathbf{0 , 8 5 1}$ & 0,599 & 0,418 \\
Completeness of products sold (X.3) & $\mathbf{0 , 7 4 9}$ & 0,504 & 0,298 \\
Convenience (X.4) & $\mathbf{0 , 7 0 6}$ & 0,474 & 0,631 \\
Information provided by E-commerce (X.5) & $\mathbf{0 , 6 6 5}$ & 0,537 & 0,337 \\
Total cost (Y1.1) & 0,508 & $\mathbf{0 , 8 8 1}$ & 0,742 \\
Total Revenue (Y1.2) & 0,643 & $\mathbf{0 , 9 3 3}$ & 0,656 \\
Time (Y1.3) & 0,674 & $\mathbf{0 , 8 7 3}$ & 0,611 \\
Reaching Sales Volume (Y2.1) & 0,650 & 0,726 & $\mathbf{0 , 8 8 6}$ \\
Earning Profit (Y2.2) & 0,377 & 0,494 & $\mathbf{0 , 8 9 9}$ \\
Supporting community growth (Y2.3) & 0,486 & 0,675 & $\mathbf{0 , 8 6 1}$ \\
\hline
\end{tabular}

Primary Data, 2020

Based on Table 3, it can be seen that the correlation of the E-Commerce construct (X) and its indicators are higher than the correlation of the indicators of Income (Y1) and Sales Volume (Y2). The correlation of the Revenue construct (Y1) with its indicator is higher than the correlation of the E-Commerce construct indicator (X) and Sales Volume (Y2). Furthermore, the correlation of the Sales Volume construct (Y2) with the indicator is higher than the correlation between the E-Commerce (X) and Revenue (Y1) indicators. Thus, it can be explained that the indicators meet the criteria for discriminant validity.

Reliability test

Based on the test results, Cronbach's Alpha and Composite Reliability each construct shows a value greater than 0.70 . The following can be seen in Table 4.

Table 4

Reliability Test

\begin{tabular}{llll}
\hline Variable & $\begin{array}{l}\text { Composite } \\
\text { Reliability }\end{array}$ & Cronbach's Alpha & Description \\
\hline E-Commerce (X) & 0,870 & 0,812 & Reliable \\
Revenue (Y1) & 0,924 & 0,878 & Reliable \\
Sales Volume (Y2) & 0,913 & 0,862 & Reliable \\
\hline
\end{tabular}

Primary Data, 2020

Mandasari, I. C. S. ., \& Pratama, I. G. S. . (2020). The use of e-commerce during COVID-19 pandemic towards revenue and volume of MSMEs sales. International Research Journal of Management, IT and Social Sciences, 7(6), 124-130. https://doi.org/10.21744/irjmis.v7n6.1022 


\subsection{Evaluation of the Structural Model (Inner Model)}

Coefficient of Determination $\left(R^{2}\right)$

Based on the results of the analysis, here is the R-Square value of the Income construct $\left(\mathrm{Y}^{1}\right)$ and Sales Volume $\left(\mathrm{Y}^{2}\right)$ which are presented in Table 5.

Table 5

$R$-Square

\begin{tabular}{ll}
\hline Variable & $R$-Square \\
\hline Revenue (Y1) & 0,474 \\
Sales Volume (Y2) & 0,360 \\
\hline
\end{tabular}

Primary Data, 2020

The goodness of fit model is measured using the R-square dependent latent variable with the same interpretation as the predictive relevance Q-square regression for the structural model. The Q-square calculation is as follows:

Q-square $=1-(1-\mathrm{R} 12)(1-\mathrm{R} 22)$

$$
\begin{aligned}
& =1-(1-0.474)(1-0.360) \\
& =1-(0.526)(0.640) \\
& =1-0.337 \\
& =0.663
\end{aligned}
$$

Based on the results of the calculation of the formula, the Q-Square value is 0.669 , so it can be concluded that the model has a good predictive relevance. It can be explained that 66.3 percent of the variation in Revenue (Y1) and Sales Volume (Y2) is explained by the E-Commerce variable (X).

\subsection{Hypothesis Testing Results}

The results of the analysis of the empirical research model using the Partial Least Square (PLS) analysis tool can be seen in the following figure:

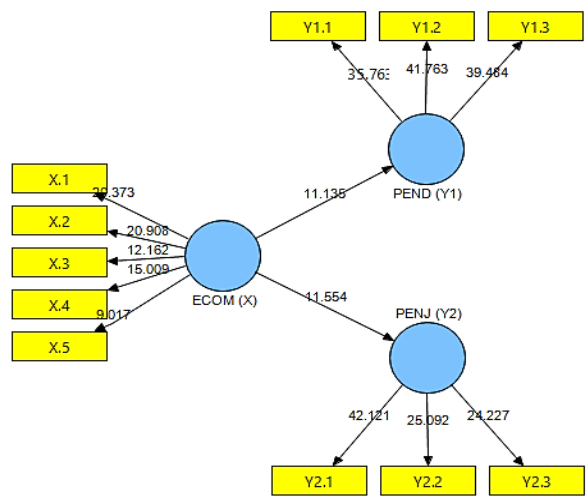

Figure 2. Empirical model

In Table 6, it shows that testing the hypothesis on the effect of E-Commerce (X) on Income (Y1) results in a correlation coefficient value of 0.688 . The value of $t$ Statistics is 11.135 (>t critical 1.96), so the effect of E-Commerce (X) on Income (Y1) is significant. Based on these results, hypothesis 1 (H1) which states that E-Commerce (X) has a positive and significant effect on income (Y1) is accepted.

Hypothesis testing on the effect of E-Commerce (X) on Sales Volume (Y2) results in a correlation coefficient value of 0.600. The value of $t$ Statistics is 11.554 ( $>t$ critical 1.96), so the effect of E-Commerce (X) on Sales Volume (Y2) is significant. Thus, hypothesis $2(\mathrm{H} 2)$ which states that E-Commerce $(\mathrm{X})$ has a positive and significant effect on Sales Volume (Y2) is accepted. 
Table 6

Path coefficient

\begin{tabular}{llll}
\hline Construct & Correlation Coefficient & $t$ Statistics & Description \\
\hline E-Commerce $(\mathrm{X}) \rightarrow$ Revenue $(\mathrm{Y} 1)$ & 0.688 & 11,135 & Significant \\
E-Commerce $(\mathrm{X}) \rightarrow$ Sales Volume (Y2) & 0.600 & 11,554 & Significant \\
\hline
\end{tabular}

Primary Data, 2020

\subsection{The impact of e-commerce before the COVID-19 and during COVID-19 on MSMEs in Denpasar City}

Based on questions on the distribution of questionnaires regarding the amount of income before the pandemic, after the pandemic, and after using e-commerce during the pandemic to 100 respondents of MSME owners in Denpasar City, the average income results are as shown in the following table:

Table 7

Total MSME income in Denpasar city

\begin{tabular}{llll}
\hline Revenue Range & Before Pandemic & After Pandemic & After Using E-Commerce \\
\hline IDR 1 - 5 mio & 30 & 85 & 63 \\
IDR 5-10 mio & 47 & 15 & 37 \\
IDR 10-15 mio & 16 & - & - \\
IDR < 15 mio & 1 & - & - \\
Mean & IDR 7.900.000 & IDR 3.270.000 & IDR 5.050.000 \\
\hline
\end{tabular}

Primary Data, 2020

Based on the table above, the income of MSMEs decreased during the COVID-19 Pandemic by 41.4\%, but with the use of e-commerce, the decreased income could increase by $64.8 \%$. This shows that during the COVID-19 Pandemic the use of e-commerce had an impact on before and after using it.

\section{Conclusion}

The description of the use of the digital marketing concept of e-commerce during the COVID-19 pandemic on revenue and sales volume has been described in the questions spread through questionnaires to MSME owners in Denpasar City. Based on the screening question regarding the income of MSMEs, it can be concluded that the income of MSMEs decreased at the beginning of the COVID-19 pandemic, but with the use of e-commerce income increased but not as much as before the COVID-19 pandemic, while the results of the data analysis using PLS, it can be concluded that ECommerce has a positive and significant effect on income, this means that using e-commerce during the COVID-19 pandemic can increase income. Also, E-Commerce has a positive and significant effect on sales volume, this means that with the use of e-commerce at MSMEs in Denpasar City during the COVID-19 pandemic, the sales volume will also increase.

\section{Conflict of interest statement}

The authors declared that they have no competing interests.

\section{Statement of authorship}

The authors have a responsibility for the conception and design of the study. The authors have approved the final article.

\section{Acknowledgments}

We are grateful to two anonymous reviewers for their valuable comments on the earlier version of this paper.

Mandasari, I. C. S. ., \& Pratama, I. G. S. . (2020). The use of e-commerce during COVID-19 pandemic towards revenue and volume of MSMEs sales. International Research Journal of Management, IT and Social Sciences, 7(6), 124-130. https://doi.org/10.21744/irjmis.v7n6.1022 


\section{References}

Abdillah, W., \& Jogiyanto. (2009). Partial Least Square (PLS) Alternatif SEM Dalam Penelitian Bisnis. Penerbit Andi: Yogyakarta. Hal 262.

Abor, J., \& Quartey, P. (2010). Issues in SME development in Ghana and South Africa. International research journal of finance and economics, 39(6), 215-228.

Chawan, A., \& Vasudevan, H. (2014). Knowledge management practices in Indian manufacturing MSMEs: challenges and opportunities. Procedia Engineering, 97, 1784-1787. https://doi.org/10.1016/j.proeng.2014.12.331

Corbitt, B. J., Thanasankit, T., \& Yi, H. (2003). Trust and e-commerce: a study of consumer perceptions. Electronic commerce research and applications, 2(3), 203-215. https://doi.org/10.1016/S1567-4223(03)00024-3

Dewi, H. U. (2019). The analysis of factors that effect business development and income of MSMEs in Denpasar city. International research journal of management, IT and social sciences, 6(4), 118-126.

Gunasekaran, A., Marri, H. B., McGaughey, R. E., \& Nebhwani, M. D. (2002). E-commerce and its impact on operations management. International journal of production economics, 75(1-2), 185-197. https://doi.org/10.1016/S0925-5273(01)00191-8

Helmalia, H., \& Afrinawati, A. (2018). Pengaruh E-Commerce Terhadap Peningkatan Pendapatan Usaha Mikro Kecil dan Menengah di Kota Padang. JEBI (Jurnal Ekonomi Dan Bisnis Islam), 3(2), 237-246.

Klok, F. A., Kruip, M. J. H. A., Van der Meer, N. J. M., Arbous, M. S., Gommers, D. A. M. P. J., Kant, K. M., ... \& Endeman, H. (2020). Incidence of thrombotic complications in critically ill ICU patients with COVID19. Thrombosis research. https://doi.org/10.1016/j.thromres.2020.04.013

Mursid, M. (2017). Manajemen Pemasaran. Edisi 1, Cetakan kesembilan.

Raut, R. D., Gardas, B. B., Jha, M. K., \& Priyadarshinee, P. (2017). Examining the critical success factors of cloud computing adoption in the MSMEs by using ISM model. The Journal of High Technology Management Research, 28(2), 125-141. https://doi.org/10.1016/j.hitech.2017.10.004

Shih, H. S., Lee, E. S., Chuang, S. H., \& Chen, C. C. (2012). A forecasting decision on the sales volume of printers in Taiwan: An exploitation of the Analytic Network Process. Computers \& Mathematics with Applications, 64(6), 1545-1556. https://doi.org/10.1016/j.camwa.2011.12.082

Siregar, S. (2010). Statistika deskriptif untuk penelitian. Jakarta: Rajawali Pers.

Stokes, J. R. (2005). Dynamic cash discounts when sales volume is stochastic. The Quarterly Review of Economics and Finance, 45(1), 144-160. https://doi.org/10.1016/j.qref.2004.08.001

Sugiyono. (2012). Metode Penelitian Bisnis. Bandung: Alfabeta

Suprapto, H. A. (2016). Pengaruh Penetapan Harga Dan E-Commerce Terhadap Tingkatpenjualan Pada Usaha Jack Donut Di Curug Tanah Baru Depok. JABE (Journal of Applied Business and Economic), 2(4), 345-354. 